\title{
The late Archaean mobile belt through Godthåbsfjord, southern West Greenland: a continent-continent collision zone?
}

\author{
V. R. McGREGOR, C. R. L. FRIEND and A. P. NUTMAN
}

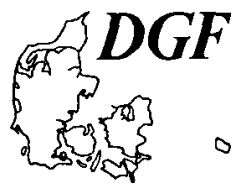

McGregor, V. R., Friend, C. R. L. \& Nutman, A. P.: The late Archaean mobile belt through Godthåbsfjord, southern West Greenland: a continent-continent collision zone? Bull. geol. Soc. Denmark, vol. 39, pp. 179-197. Copenhagen, December 20th, 1991. https://doi.org/10.37570/bgsd-1991-39-08

\begin{abstract}
In the Godthåbsfjord region of southern West Greenland a NE-SW-trending belt of rocks of very varied age and origin, here named the Akulleq terrane, is separated by major faults from more extensive blocks of typical high-grade Archaean rocks that, although they are superficially similar, have different ages and metamorphic histories. The continental crust that forms the block to the north-west, the Akiaterrane, was accreted between ca. 3200 and $2980 \mathrm{Ma}$, and that forming the block to the south-east, the Tasiusarsuaq terrane, between 2920 and $2800 \mathrm{Ma}$. It issuggested that the Godthåbsfjord belt is the result of collision of the two continentalblocksbetween 2800 and $2650 \mathrm{Ma}$. The rocksof the Akulleq terrane are interpreted as fragments of different parts of the crust that originally separated the two continents. They include early Archaean continental crust, possible oceanic crust, and acid to intermediate rocks of intrusive and possibly also extrusive origin that may have been generated in a subduction-related environment.
\end{abstract}

V. R. McGregor, Atammik, DK-3912 Maniitsoq, Greenland. C. R. L. Friend, Department of Geology, Oxford Polytechnic, Oxford OX3 OBP, Oxon, U.K. A. P. Nutman, Research School of Earth Sciences, Australian National University, Canberra 2601, Australia. October 2nd, 1990.

A major breakthrough in understanding the complex, high-grade Archaean geology of the Godthåbsfjord region of southern West Greenland was the recognition between 1985 and 1988 of three major blocks or terranes separated from one another by tectonic breaks. The blocks had quite different lithological associations and histories before they were juxtaposed in the late Archaean (Friend et al. 1987, 1988b, Nutman et al. 1989). Previously it had been assumed that the geology was essentially continuous across the whole region (McGregor et al. 1986).

The first recognition of a major tectonic break came from our attempts to delimit the extent of late Archaean granulite facies metamorphism between Godthåbsfjord and Fiskenæsset. During reconnaissance work over several field seasons in the first half of the 1980s we established a number of textural criteria for recognising rocks retrogressed from granulite facies (McGregor et al. 1986), and confirmed the interpretation of Windley (1972) that the rocks in the coastal strip from Fiskenæsset north to around Færingehavn, as well as in the inner part of Buksefjorden and the middle section of Ameralik, had been metamorphosed to granulite facies, but subsequently largely retrogressed to amphibolite facies. We assumed that before retrogression there must have been a prograde amphibolite facies to granulite facies transition extending through Færingehavn, outer Buksefjorden and Ameralik (McGregor et al. 1986), and the main aim of our field work in 1984 and 1985 was to locate and study this prograde zone. However in 1985, during detailed remapping in the Færingehavn - Tre Brødre area and reconnaissance work in Buksefjorden and Ameralik, we found a sharp, mappable boundary between rocks to the south-east that had been retrogressed from granulite facies and rocks to the north-west that had never reached granulite facies. Although this boundary had been modified by intense later deformation, we concluded that it must be a major fault. In the central section of Ameralik rocks retrogressed from granulite facies form the cores of synforms and overlie rocks that never reached granulite facies, suggesting that the boundary was originally a thrust. During helicopter reconnaissance in 1987 the fault was traced across the area south of inner Ameralik, where it is less modified by later deformation and its thrust nature is clearer. It was named the Qarliit nunaat thrust (Friend et 
al. 1988a). The block affected by late Archaean granulite facies metamorphism south-east of the thrust was named the Tasiusarsuaq terrane (Friend et al. 1987).

The detailed mapping in 1985 showed that in the Faringehavn - Tre Brødre area early Archaean Amîtsoq gneisses and enclosed supracrustal and other lithologies are separated by zones of deformed blastomylonites from an association of lithologies that includes supracrustal rocks (mainly quartz-cordierite gneisses), layered metabasic rocks (leucogabbro, anorthosite, melagabbro) and a small component of Amitsoq gneisses, all intruded by voluminous, mainly granodioritic, quartzo-feldspathic gneisses. The name Ikkattoq gneisses was proposed for the intrusive quartzo-feldspathic gneisses (Friend et al. 1988b). Conventional bulk zircon dating gave discordant results, with a maximum ${ }^{207} \mathrm{~Pb}-{ }^{206} \mathrm{~Pb}$ age of ca. $2790 \mathrm{Ma}$ for the least discordant sample (Nutman et al. 1989). Because all contacts between on the one hand the major units of early Archaean rocks and on the other the Ikkattoq gneisses and the lithologies they intrude are tectonic in the Færingehavn - Tre Brødre area, these lithological associations were assigned to separate terranes, named respectively the Færingehavn terrane and the Tre Brødre terrane (Friend et al. 1987). During 1987 they were traced over a large area in inner Ameralik and Kapisillit fjord (Friend \& Nutman 1988). However field work in 1988 and 1989 confirmed the observations of earlier field work (McGregor 1973) that gneisses of Ikkattoq type clearly intrude the type Amîtsoq gneisses in outer Ameralik and Kobbefjord and on Storø in Godthåbsfjord. It now appears that while relations between the early Archaean rocks and the younger supracrustal sequences along with associated layered metabasic intrusions may be mainly or entirely tectonic, all these lithological associations were intruded by Ikkattoq gneisses (see below). Thus the tectonic separation of the Amitsoq gneisses and Ikkattoq gneisses in the Færingehavn - Tre Brødre area and the division of the geology into Færingehavn and Tre Brødre terranes appear to be local rather than regional features. The name Akulleq terrane is introduced here for the belt of complex geology north-west of the Qarliit nunaat thrust that includes all the rocks originally assigned to the Færingehavn and Tre Brødre terranes. "Akulleq" is Greenlandic for "the one in the middle".

A second regional break that separates the Akulleq terrane from mid-Archaean gneisses and enclosed supracrustal rocks to the north-west was recognised in 1987 in the area around Nuuk (Godthåb) town and was traced north as far as Ilulialik in inner Godthåbsfjord in 1988. The name Ivinnguit fault is introduced here for this break, from a locality where it cuts the south-east coast of Bjørneøen in Godthåbsfjord. The block of mid-Archaean rocks to the north-west was named the Akia terrane (Friend et al. 1988a).

Some of the stratigraphic groupings introduced in the late 1960s and early 1970s include rocks of quite different ages and origins in different terranes. The term Malene supracrustals was applied to all supracrustal rocks of presumed mid-Archaean age in the Godthåbsfjord region (McGregor 1969, 1973). It is now apparent that this includes amphibolites of probable mid-Archaean age in the Akia terrane, amphibolites, quartzcordierite gneisses and clastic metasediments of late Archaean age in the Akulleq terrane, and mid-late Archaean amphibolites in the Tasiusarsuaq terrane. We recommend that the use of the term Malene supracrustals be discontinued. No new formational names are proposed for these rocks since it is uncertain to what extent they originally formed continuous sequences or, more likely, are fragments of a number of sequences that were juxtaposed during terrane formation and accretion. The term Nâk gneisses was used in earlier papers for all quartzo-feldspathic gneisses in the Godthåbsfjord region that did not contain Ameralik dykes and that intruded and migma-

\footnotetext{
Fig. 1 (opposite). Sketch map of the Godthåbsfjord region showing the disposition of the Akia, Akulleq and Tasiusarsuaq terranes as defined in this paper. There is still some doubt as to the true disposition of the boundaries in the area north-east of Godthåbsfjord towards Isukasia. The position of the granulite-amphibolite facies transition zone in the area north of the head of Bjørnesund is unknown. The map is compiled from the 1:500 000 and 1:100 000 map sheets published by the Geological Survey of Greenland (Grønlands Geologiske Undersøgelse) and our own published and unpublished data. Terrane boundaries are marked: If = Ivinnguit fault; Qnt = Qarliit nunaat thrust. Key to place names: B = Bjørneøen; Buk = Buksefjorden; F = Fiskenæsset; Fh $=$ Færingehavn; I $=$ Ililualik; Ka $=$ Kapisillit; Ko $=$ Kobberfjord; $Q=$ Qooqqut; Qi $=$ Qilanngaarsuit; Qk = Qussuk; S $=$ Sadelø; TB $=$ Tre Brødre. A list of Greenlandic place names with old and new spellings is to be found at the end of this paper, after References.
} 


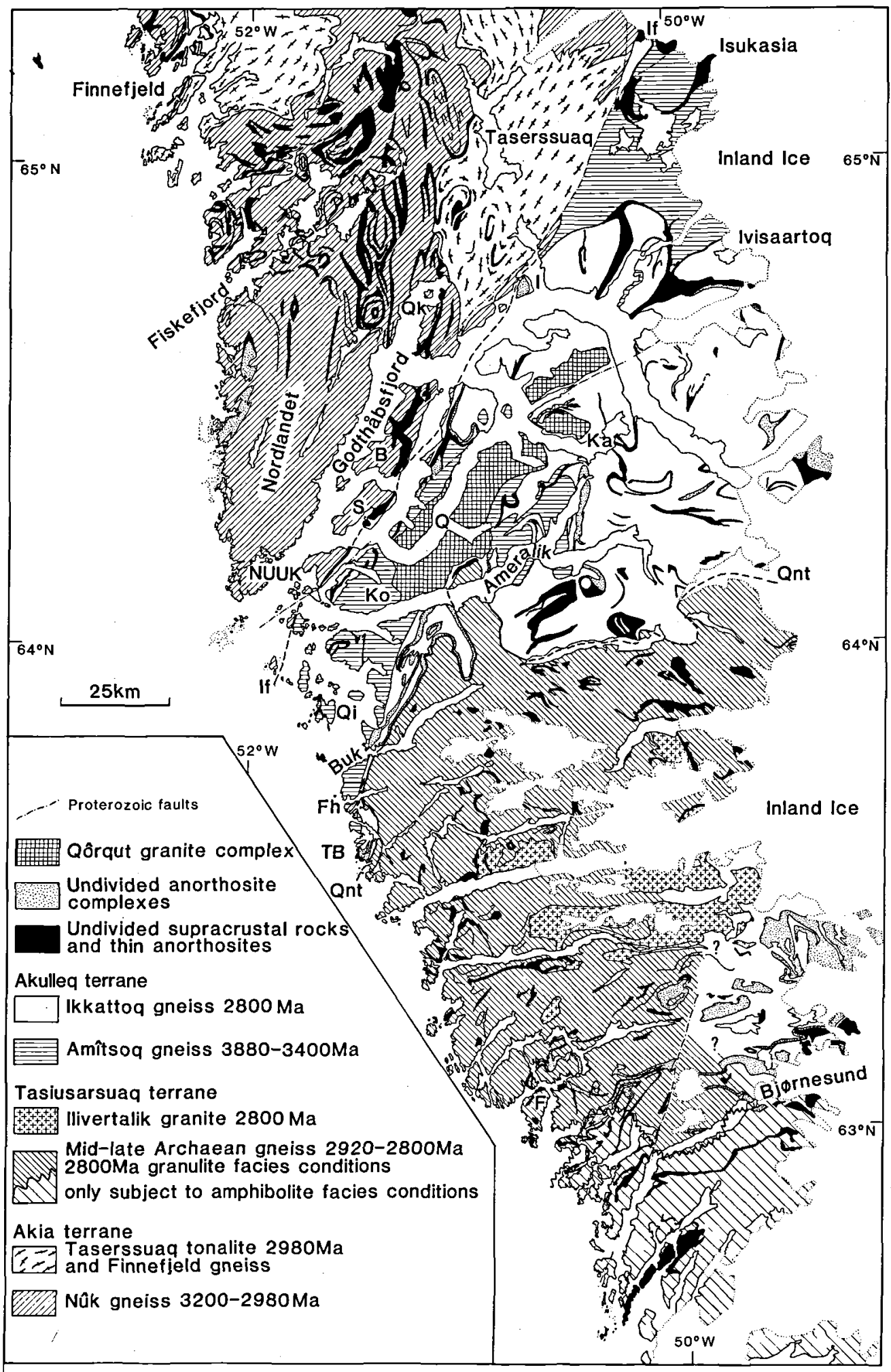


tised Amîtsoq gneisses, Malene supracrustal rocks and the associated metabasic intrusive rocks (McGregor 1973, 1979). The term Nûk gneisses is now restricted to the type rocks around the town of Nuuk and on Sadelø and Bjørneøen (Baadsgaard \& McGregor 1981) and to other gneisses in the Akia terrane that can be correlated with them (Nutman et al. 1989). All or most of the rocks mapped as Nûk gneisses within the Akulleq terrane can probably be included within the Ikkattoq gneisses.

The present paper provides a status report on our interpretation of the geology of the Godthåbsfjord region. We demonstrate that this region comprises two blocks of continental crust formed by similar processes in the middle and late Archaean respectively, and a complex belt between them made up of rocks of very different lithologies, ages and provenances, that were welded into a single entity in the late Archaean. A number of new, as yet unpublished, SHRIMP (sensitive high-resolution ion microprobe) ages determined at Australian National University, Canberra, within the last year are referred to here.

We follow Harland et al.'s (1982) division of the Archaean into early (4000-3400 Ma), middle (3400-2900 Ma) and late (2900-2500 Ma). Place names are spelt using the new orthography, official in Greenland since 1973. Since these spellings are to be found on only very few published maps, a list of place names with new and old spelling is provided at the end of this paper. The old orthography is however retained for stratigraphic terms originally defined when this was in use.

\section{The northern block (Akia terrane)}

The Akia terrane is dominated by mid-Archaean dioritic, tonalitic, trondhjemitic and granitic gneisses together with supracrustal rocks, mainly amphibolites, and small amounts of metabasic intrusive rocks (leucogabbro, norite). Most of the terrane was affected by granulite facies metamorphism which was shown by $\mathrm{Pb}-\mathrm{Pb}$ whole rock studies (Taylor et al. 1980) and SHRIMP dating of zircon overgrowths $(\mathrm{H}$. Baadsgaard, pers. comm.) to have occurred at ca. $3000 \mathrm{Ma}$.

Dioritic gneisses are the dominant lithology on the Nordland peninsula west of Godthåbsfjord and are a minor, but widespread, component of the geology over a much wider area. Preliminary SHRIMP dating of zircons indicates that dioritic gneisses on southern Nordland are ca. $3200 \mathrm{Ma}$ old (H. Baadsgaard, pers. comm.). Tonalitic gneisses form continuous belts between the major units of dioritic gneiss on northern Nordlandet and are the dominant lithology to the north and north-east. Tonalitic gneisses from Bjørnewen in the south-eastern part of the terrane, where the metamorphic grade never exceeded amphibolite facies, have given conventional bulk zircon concordia-intercept $\mathrm{U}-\mathrm{Pb}$ ages of 3070 3000 Ma (Baadsgaard \& McGregor 1981) and SHRIMP concordant ages of $3040-3000 \mathrm{Ma}(\mathrm{H}$. Baadsgaard, pers. comm.). Large, relatively homogeneous bodies of granodioritic gneiss that intrude the tonalitic gneisses in this area have given bulk zircon concordia-intercept U-Pb ages of ca. 2980 Ma (Baadsgaard \& McGregor 1981) and a $\mathrm{Rb}$-Sr whole rock isochron age of $2980 \pm 50 \mathrm{Ma}$ (Taylor et al. 1980). North of inner Godthåbsfjord the Taserssuaq tonalite, made up of relatively weakly deformed tonalitic, granodioritic and minor more basic phases, crops out over an area of $2200 \mathrm{~km}^{2}$. It has yielded a conventional concordia-intercept zircon age of $2982 \pm 7 \mathrm{Ma}$ (Garde et al. 1986).

The tonalitic gneisses enclose many rafts and larger units of amphibolite, including both layered and massive types. Relict pillow-lava and agglomerate structures have been recognised at a few localities, but in most units primary structures have been erased by strong deformation. On Sadelø and Bjørneøen the supracrustal rocks include some with komatiitic composition that locally appear to have relict pillow structures, and abundant large pods of massive olivine-pyroxene-hornblende ultramafic rocks. Small amounts of metasedimentary gneisses occur locally with the amphibolites, for example white garnet-sillimanite-cordierite-bearing quartzofeldspathic gneisses in central Nordlandet. A large but highly fragmented body of leucogabbro, intruded by both dioritic and tonalitic gneisses, crops out in a complex synclinorium on western Nordlandet. It is underlain by a unit of supracrustal amphibolite with minor metasediments, but there is no clear evidence of the relative ages of the leucogabbro and the supracrustal rocks.

The south-easternmost part of the Akia ter- 
rane - a narrow belt immediately west of the Ivinnguit fault that includes the Nuuk peninsula, Sadelø, Bjørneøen and part of the peninsula between Qussuk and inner Godthåbsfjord - was never metamorphosed above amphibolite facies. Most of the rest of the terrane was metamorphosed to granulite facies, with peak metamorphic conditions on Nordlandet estimated to have been $800 \pm 50^{\circ} \mathrm{C}$ and $7.9 \pm 1.0 \mathrm{kbar}$ (Nutman et al. 1989, Riciputi et al. 1990). There was retrogression to amphibolite facies over large areas (Garde 1989, 1990), at least part of which was the result of influx of water associated with late deformation. This is clearest in and adjacent to the late belt of intense ductile deformation that extends through rocks retrogressed from granulite facies along the east coast of Nordlandet and the west side of Qussuk (see below). The combined effects of retrogression and late deformation have obscured the original prograde amphibolite to granulite facies transition. Textural evidence in the retrogressed, amphibolite facies rocks indicates that it passed through the north-eastern corner of Qussuk.

Weakly deformed, very leucocratic, coarsegrained trondhjemitic and less common granitic gneisses break up the dioritic and tonalitic gneisses and the supracrustal rocks. They occur as diffusely bounded patches and veins in the dioritic gneisses, as sharply cross-cutting sheets, some quite undeformed, and as the cores of several diapiric domes that post-date more than one generation of early folds. Orthopyroxene is generally absent from larger bodies of the late trondhjemitic and granitic gneisses, but is common in smaller bodies. Small intrusive bodies of late, plagioclase-rich diorites occur in or adjacent to mafic lithologies. Pillar (1985) suggested that they were the products of partial melting of mafic parents in the presence of hydrous fluids, possibly in the early stages of granulite facies metamorphism. In rocks where there is no evidence of retrogression associated with influx of water, the pyroxenes are commonly rimmed by dark green hornblende and the ore minerals by sheaves of biotite. Pillar (op. cit.) suggested that the late hornblende was the result of reactions involving a small amount of residual melt on grain boundaries during cooling from peak metamorphic conditions. He found variable $\mathrm{a}_{\mathrm{H}_{2} \mathrm{O}}$ in samples collected from adjacent outcrops and concluded that there could not have been a pervasive fluid of constant composition and thus no regional influx of $\mathrm{CO}_{2}$. Low values of $f_{\mathrm{H}_{2} \mathrm{O}}$ and $f_{\mathrm{CO}_{2}}$ estimated by Riciputi et al. (1990) suggest that conditions were fluid-absent at the peak of metamorphism.

The extent of the Akia terrane towards the north is uncertain. The geology is continuous in the coastal strip at least as far north as $65^{\circ} \mathrm{N}$, where rocks similar to those on Nordlandet are cut by a large body of post-granulite facies tonalitic gneiss, the Finnefjeld gneiss (Berthelsen 1962, Marker \& Garde 1988). From the Finnefjeld gneiss north to the boundary of the Proterozoic Nagssugtoqidian mobile belt in the Søndre Strømfjord region all the rocks have been metamorphosed to granulite facies. Between the Finnefjeld gneiss and Maniitsoq (Sukkertopppen) there was extensive retrogression to amphibolite facies associated with deformation. Essentially unretrogressed granulite facies rocks extend continuously north from Maniitsoq to the Nagssugtoqidian boundary. A major change in the geology is the relative abundance of metasedimentary gneisses in the supracrustal units north of the Finnefjeld gneiss as far as Evighedsfjord compared with their scarcity to the south. The fact that gneisses from Maniitsoq lie on the same 3000 $\mathrm{Ma} \mathrm{Pb-Pb}$ whole-rock isochron as rocks from Nordlandet (Taylor et al. 1980) suggests that the Akia terrane continues north of the Finnefjeld gneiss. However F. Kalsbeek (pers. comm.) has obtained a $\mathrm{Rb}-\mathrm{Sr}$ whole-rock isochron age of $2625 \pm 75 \mathrm{Ma}$ with $\mathrm{Sr}_{\mathrm{i}}=0.7063 \pm 0.0012$ from granulite facies supracrustal rocks from Hamborgerland, $25 \mathrm{~km}$ north of Maniitsoq.

\section{The southern block (Tasiusarsuaq terrane)}

Rocks that were metamorphosed to granulite facies extend from the Qarliit nunaat thrust south for $120 \mathrm{~km}$ to inner Bjørnesund, where a well preserved prograde, amphibolite facies to granulite facies transition has been recognised (McGregor \& Friend in prep.). There has been very extensive retrogression to amphibolite facies. Rocks in which orthopyroxene is preserved occur as discontinuous areas and patches on all scales. There is no evidence of any major post-granulite facies break in the geology south of the Qarliit 
Table 1. Archaean geological evolution of the Godthåbsfjord area and adjacent regions.

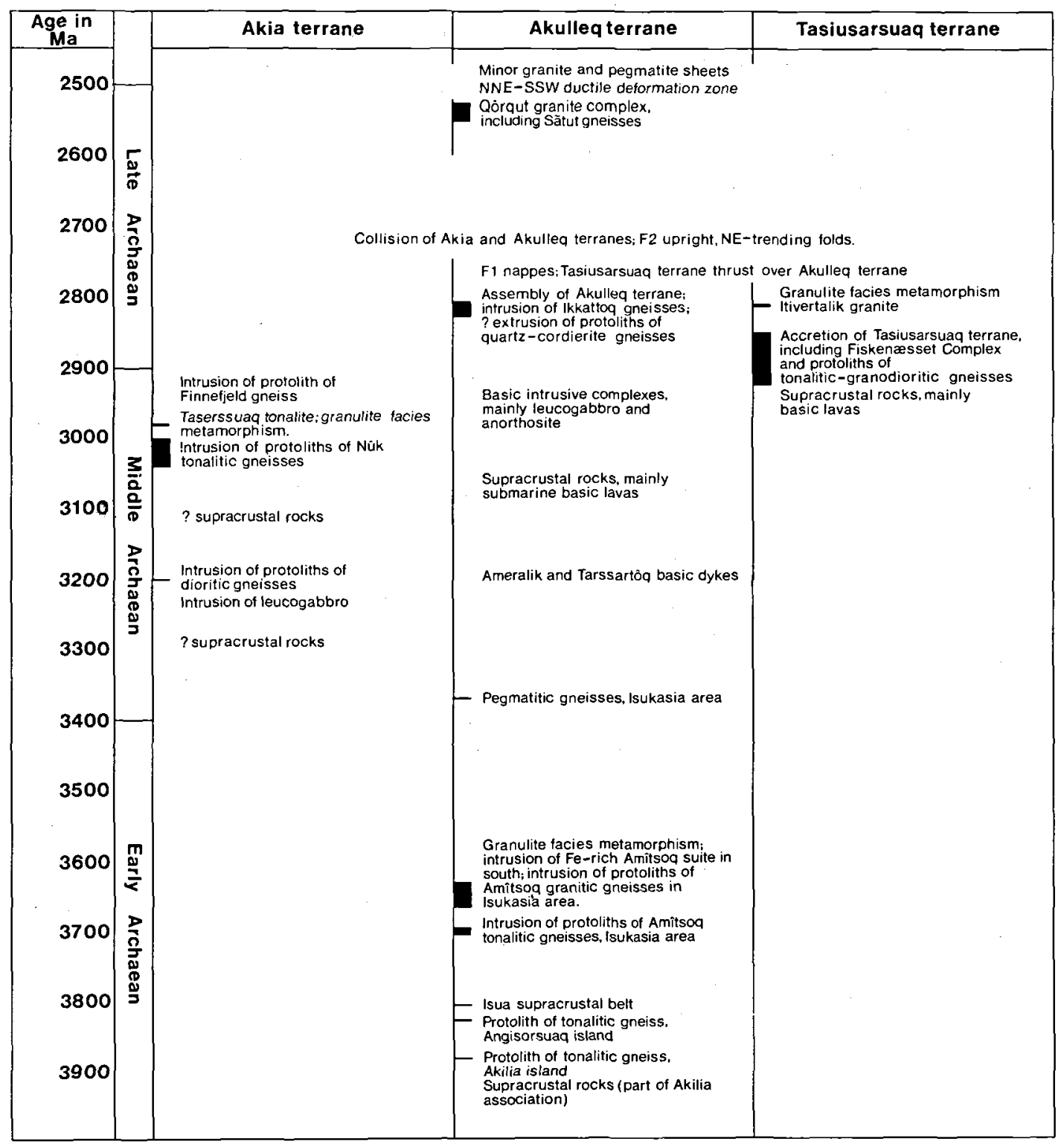

nunaat thrust at least as far as the mouth of Bjørnesund. The whole of this tract is therefore considered to belong to the Tasiusarsuaq terrane.

Like the Akia terrane, the Tasiusarsuaq terrane is dominated by tonalitic gneisses that were intruded as sheets into sequences of mainly basic volcanic rocks that now occur as layers (generally less than $500 \mathrm{~m}$ thick) and rafts of amphibolite with a very subordinate sedimentary component (Myers 1976, Kalsbeek \& Garde 1989). Com- pared with the Akia terrane there is less dioritic gneiss and apparently more granodioritic gneiss. In an ENE-WSW-trending belt $40 \mathrm{~km}$ wide between Fiskenæsset and Bjørnesund the gneisses also enclose layers and rafts derived from a major layered complex of deformed and metamorphosed anorthosite, leucogabbro, gabbro and peridotite, the Fiskenasset Complex (Myers 1981, 1985). Similar rocks crop out locally farther north in the terrane, for example immediately above 
the Qarliit nunaat thrust on both sides of Ameralik. Just north of and overlapping with the belt in which the Fiskenæsset Complex occurs there are very extensive outcrops of deformed porphyritic granite, the Ilivertalik granite, associated with metadiorite and metatonalite. The granite forms three thick and numerous thin sheets. It postdates major recumbent isoclinal folds in the earlier rocks and was itself deformed by two phases of major folding.

Isotopic evidence indicates that the main components of the Tasiusarsuaq terrane have primary crystallisation ages of $2920-2800 \mathrm{Ma}$. The oldest isotopic age obtained from the terrane is a SHRIMP age of $2922 \pm 7$ Ma on zircons with igneous features from a gneiss that contains metamorphosed basic dykes $12 \mathrm{~km}$ south-east of the Qarliit nunaat thrust (Schiøtte et al. 1989a). Gneisses with metamorphosed basic dykes from two other localities close to the thrust contain zircons with cores that have given SHRIMP ages of $2840 \mathrm{Ma}$ (two samples) and $2826 \mathrm{Ma}$ (P. Kinny 1987 and pers. comm.). A Sm-Nd isochron age of $2860 \pm 50 \mathrm{Ma}$ has been obtained on samples from the Fiskenæsset Complex (Ashwal et al. 1989). Zircons from a tonalitic gneiss that cuts leucogabbro of the Fiskenæsset Complex near the mouth of Bjørnesund, where the rocks did not reach granulite facies, have given a SHRIMP age of $2863 \pm 8 \mathrm{Ma}(2 \sigma)$ (Nutman, unpublished data). A granulite facies sample of the Ilivertalik granite from the northern margin of the belt in which the Fiskenæsset Complex crops out has given a bulk zircon concordia-intercept age of $2795 \pm 11$ Ma (Pidgeon et al. 1976, Pidgeon \& Kalsbeek 1978). Reconnaissance SHRIMP zircon dating of a granulite facies sample of Ilivertalik granite from Sermilik has given an age of $2814 \pm$ $14 \mathrm{Ma} \mathrm{(2 \sigma )} \mathrm{(Nutman,} \mathrm{unpublished} \mathrm{data).} \mathrm{A} \mathrm{near-}$ concordant age of $2790 \mathrm{Ma}$ for a large, euhedral zircon grain from a mafic pod in anorthosite within granulite facies rocks was considered by Pidgeon \& Kalsbeek (1978) to date the granulite facies metamorphism. These results imply that the whole of the plutonic development of the Tasiusarsuaq terrane, including the intrusion of the magmatic parents of the Fiskenæsset Complex and the gneisses, intrusion of the Ilivertalik granite, three major phases of folding and granulite facies metamorphism, took place within a period of little more than $100 \mathrm{Ma}$.
Several lines of evidence suggest that the Tasiusarsuaq terrane is a tilted crustal section from the time of the formation of the Qarliit nunaat thrust with progressively deeper levels exposed from south-east (Bjørnesund) to north-west (Qarliit nunaat thrust) (McGregor \& Friend, in prep.). The section has been strongly modified by deformation that post-dates the thrust. Peak metamorphic conditions within $10 \mathrm{~km}$ of the thrust are estimated to have been $780 \pm 60^{\circ} \mathrm{C}$ and $8.9 \pm 1.0$ kbar (Nutman et al. 1989, Riciputi et al. 1990). There is little field evidence of partial melting associated with granulite facies metamorphism in this terrane except in the deepest level adjacent to the Qarliit nunaat thrust where melting of intermediate to basic lithologies gave rise to minor diorites. These are more mafic than the syngranulite facies diorites in the Akia terrane. In the prograde transition zone in inner $\mathrm{Bj} \varnothing$ rnesund orthopyroxene grew at the expense of hornblende in a wide variety of lithologies without the formation of significant quantities of melt. There are no syn-granulite facies veins of trondhjemite or granite, and orthopyroxene grains do not have rims of late hornblende, as in the Akia terrane. A sharp, but highly irregular, front that crosses lithological boundaries separates orthopyroxenebearing rocks from orthopyroxene-free rocks on outcrop scale. The field evidence suggests that in the prograde transition zone orthopyroxene formed as the result of influx of fluids with low $a_{\mathrm{H}_{2} \mathrm{O}}$ and presumably high $\mathrm{a}_{\mathrm{CO}_{2}}$. This may not be true of deeper levels in the Tasiusarsuaq terrane. Riciputi et al. (1990) reported low estimates of $f_{\mathrm{CO}_{2}}$ in the northern part of the terrane.

In unretrogressed areas granulite facies metamorphism outlasted deformation. In other areas retrogression of the granulite faces rocks was associated with widespread ductile deformation. It involved influx of hydrous fluids that migrated upwards from below the Qarliit nunaat thrust (Friend et al. 1988a) and along and out from deformation zones. The retrogressing fluids carried $\mathrm{Pb}$ and probably other elements from rocks of the Akulleq terrane underneath the thrust into the northern part of the Tasiusarsuaq terrane (Nutman \& Friend 1989). 


\section{The Godthåbsfjord belt (Akulleq terrane)}

The NE-SW-trending belt between the Ivinnguit fault and the Qarliit nunaat thrust is made up of four main lithological associations of very different age and origin that have been intercalated by tectonic and intrusive processes. These are:

(1) Early Archaean rocks

(2) Supracrustal rocks not intruded by Amîtsoq gneisses

(3) Layered metabasic intrusive rocks

(4) Ikkattoq gneisses.

\section{(1) Early Archaean rocks}

The early Archaean rocks were originally separated out because they contain very abundant amphibolites derived from basic dykes, the $\mathrm{Am}$ eralik dykes, that are absent from the other lithological units in the Akulleq terrane (McGregor 1973). In the Isukasia area similar dykes locally retain many igneous features and are termed the Tarssartôq dykes (Nutman et al. 1983). Extensive isotopic work has demonstrated that the rocks cut by Ameralik and Tarssartôq dykes range in age from 3880 (Nutman, unpublished data) to 3400 Ma (see McGregor et al. 1986 for references). The early Archaean rocks are dominantly variable, polygenetic, quartzo-feldspathic gneisses grouped under the term Amitsoq gneisses. They enclose and intrude a variety of supracrustal and basic and ultrabasic intrusive lithologies, the largest unit of which forms a $35 \mathrm{~km}$-long arcuate tract termed the Isua supracrustal belt (Nutman et al. 1983, Nutman 1986). The remaining occurrences of pre-Amitsoq gneiss rocks are included under the name Akilia association (McGregor \& Mason 1977). The early Archaean rocks occur as structural units of variable size separated by units of younger rocks. Most of the outcrops belong to two major units that are not connected.

(a) The southern and larger unit includes the type Amitsoq gneisses in outer Ameralik (McGregor 1973) and extends south through the islands between the mouths of Ameralik and Buksefjorden to the Færingehavn - Tre Brødre area (Friend et al. 1987) and north and east to Stor $\varnothing$ and, through rafts and the roof zone in the Qôrqut granite complex, to inner Ameralik. A characteristic feature of this unit is the fact that the rocks were metamorphosed to granulite facies at ca. $3630 \mathrm{Ma}$, before intrusion of the Ameralik dykes (Griffin et al. 1980, Baadsgaard et al. 1984, Kinny 1986). Relict granulite facies mineral assemblages are preserved on small islands south of Qilanngaarsuit and near Færingehavn. Relict granulite facies textures in totally retrogressed rocks have been observed where later deformation has been weak as far north as Qooqqut, as far east as Itilleq in inner Ameralik and as far south as the Tre Brødre area. Another characteristic feature of the southern part of the unit is the presence of an Fe-rich suite of granodioritic augen gneisses and ferrodioritic gneisses (Nutman et al. 1984). Zircons in an augen gneiss from the mouth of Ameralik have given a SHRIMP age of $3659 \pm 11 \mathrm{Ma}$ (P. Kinny, pers. comm.), showing that the suite is about the same age as the granulite facies metamorphism and may be genetically related to it. Rocks of the Fe-rich suite are widespread between Ameralik and Tre Brødre, but have not been recognised north of Ameralik. Most isotopic ages from the southern unit cluster around $3600-3650 \mathrm{Ma}$ and probably reflect resetting associated with granulite facies metamorphism (Baadsgaard et al. 1984, Kinny 1986). However SHRIMP zircon dates of $3822 \pm 5 \mathrm{Ma}$ (Kinny 1986) and $3877 \pm 10 \mathrm{Ma}(2 \sigma)$ (Nutman, unpublished data) from tonalitic gneisses that intrude the type Akilia association on islands south of the mouth of Ameralik show that this unit includes rocks older than anything recognised from unit (b) to the north.

(b) Rocks characterised by abundant metamorphosed basic dykes and typical Akilia association lithologies such as banded ironstones and clinopyroxene-hornblende rocks extend from northern Ivisaartoq along the margin of the Inland Ice north to the Isukasia area, where they include the Isua supracrustal belt. This unit (b) is separated from unit (a) by supracrustal amphibolites and Ikkattoq gneisses, and it appears to be structurally above unit (a). There is no evidence to suggest that the rocks in unit (b) reached granulite facies and there are no rocks in the unit equivalent to the Fe-rich suite of unit (a). The best dates from the Isua supracrustal belt are a SHRIMP zircon date of $3807 \pm 1 \mathrm{Ma}$ (Compston et al. 1986) and a multigrain conventional zircon concordia-intercept date of $3813 \pm 7 \mathrm{Ma}$ (Baads- 
Table 2. Analyses of Nûk and Ikkattoq gneisses

\begin{tabular}{lccc}
\hline & 1 & 2 & 3 \\
\hline $\mathrm{SiO}_{2}$ & 71.7 & 71.3 & 59.0 \\
$\mathrm{TiO}_{2}$ & 0.20 & 0.30 & 0.80 \\
$\mathrm{Al}_{2} \mathrm{O}_{3}$ & 15.4 & 14.5 & 15.90 \\
$\mathrm{Fe}_{2} \mathrm{O}_{3}$ & 1.5 & 2.5 & 7.54 \\
$\mathrm{MnO}$ & 0.02 & 0.04 & 0.10 \\
$\mathrm{MgO}$ & 0.5 & 0.7 & 3.66 \\
$\mathrm{CaO}$ & 2.2 & 2.5 & 6.72 \\
$\mathrm{Na}$ & 5.0 & 3.6 & 3.23 \\
$\mathrm{~K}_{2} \mathrm{O}$ & 2.6 & 3.4 & 1.25 \\
$\mathrm{P} \mathrm{O}_{5}$ & 0.08 & 0.05 & 0.29 \\
$\mathrm{l.o.i.}$ & & & 0.36 \\
& & & 100.53 \\
$\mathrm{Trace}$ & $\mathrm{r}$ & & \\
$\mathrm{Rb}$ & 53 & 113 & 34 \\
$\mathrm{Sr}$ & 562 & 85 & 317 \\
$\mathrm{Ba}$ & 1017 & 757 & 288 \\
$\mathrm{Y}$ & $<2$ & 23 & 27 \\
$\mathrm{~Pb}$ & 24 & 21 & 10 \\
$\mathrm{Zr}$ & 107 & 158 & 177 \\
$\mathrm{Nb}$ & 2 & 9 & 12 \\
$\mathrm{Cr}$ & 24 & $<1$ & 56 \\
\hline
\end{tabular}

1. Average of 13 amphibolite facies Nûk granodioritic gneisses, south-eastern Akia terrane (McGregor 1979).

2. Average of 4 lkkattoq granodioritic gneisses, Færingehavn Tre Brødre area, Akulleq terrane.

3. Ikkattoq dioritic gneiss (85-363), Færingehavn - Tre Brødre area, Akulleq terrane.

All chemical analyses on Ikkattoq gneisses were performed in the geochemical laboratories of the Department of Earth Sciences, Memorial University of Newfoundland, Canada. Major element analyses were obtained by atomic absorption spectrophotometry and colourimetry by G. Andrews. Trace element data were obtained by $\mathrm{X}$-ray fluorescence spectrometry on pressed powder pellets.

gaard et al. 1984). Dating by several methods shows that the dominant tonalitic gneisses that enclose and intrude the Isua supracrustal belt are $3690 \pm 50 \mathrm{Ma}$, and the granitic gneisses that intrude the tonalitic gneisses as anastomising sheets are $3590 \pm 40 \mathrm{Ma}$, while minor pegmatitic gneisses are $3370 \pm 60 \mathrm{Ma}$ (Baadsgaard et al. 1986).

Gneisses that contain fragments of basic dykes similar to the Ameralik dykes crop out adjacent to the Akulleq terrane in both the Akia and Tasiusarsuaq terranes and were originally mapped as Amîtsoq gneiss (McGregor 1973, 1984, McGregor et al. 1986) before the Qarliit nunaat thrust and the Ivinnguit fault were recognised. Isotopic studies on the supposed Amitsoq gneisses in the northern part of the Tasiusarsuaq terrane give no indication af an early Archaean age (Jones et al. 1986, Kinny 1987, Collerson et al. 1989, Nutman \& Friend 1989, Schiøtte et al. 1989a).

(2) Supracrustal rocks not intruded by Amîtsoq gneisses

Supracrustal rocks in the Akulleq terrane are more varied than in the Akia and Tasiusarsuaq terranes. They occur as thin but very continuous units intercalated with the early Archaean rocks and as layers and enclaves enclosed in and intruded by the Ikkattoq gneisses. Several lithological associations can be distinguished.

Amphibolite is the most abundant supracrustal lithology in the Akulleq terrane and forms sequences with minor ultramafic rocks, but with other supracrustal lithologies absent or very subordinate. The best preserved and thickest unit is on Ivisaartoq in inner Godthåbsfjord, where many primary structures are recognisable even though the rocks have been metamorphosed to amphibolite facies (Hall 1980, Hall et al. 1987, Chadwick 1990). Pillow-lava structures are preserved in rocks with a continuum of compositions from low-K tholeiitic to komatiitic. Diopside, epidote, garnet, carbonate and locally scheelite in veins and the cores of pillows are considered to reflect sea-floor and metamorphic alteration (Appel 1988, Chadwick 1990). The pillow-structured rocks are intercalated with concordant, homogeneous amphibolites interpreted as derived from massive flows and sills. The amphibolites enclose very continuous sheets of olivine-rich rocks derived from dunites and subordinate harzburgites. Gradation of some of the ultrabasic rocks into metagabbros led Chadwick (1990) to conclude that they were differentiated sills intruded into the submarine lavas. On the basis of the primitive chemistry of the Ivisaartoq basic rocks compared with the more evolved chemistry of the Ameralik dykes (Gill \& Bridgwater 1979, Chadwick 1981), Hall et al. (1987) suggested that the Ivisaartoq metavolcanics were not erupted through and onto early Archaean continental crust, but are a fragment of oceanic crust. Elsewhere in the Akulleq terrane the basic supracrustal rocks have been transformed by intense deformation into layered amphibolites. In many places they have discontinuous layers containing diop- 
side, epidote, scapolite and sphene, indicating that they were derived from altered pillow lavas.

Quartz-cordierite gneisses are the next most abundant type of younger supracrustal rocks in the Akulleq terrane. They are quartz-rich, aluminous, ferromagnesian gneisses with the mineralogy quartz + cordierite \pm orthoamphibole, sillimanite, garnet, biotite and staurolite (Beech \& Chadwick 1980, Dymek \& Smith 1990). They make up a unit more than $100 \mathrm{~m}$ thick that can be traced for several tens of kilometres in the southwestern part of the terrane in contact, but not interlayered, with amphibolites. The unit is compositionally layered, although in places it is remarkably massive and homogeneous. Similar rocks, possibly belonging to the same unit, crop out in several other areas within the terrane. Baadsgaard (1976) reported a near-concordant date of $2720 \mathrm{Ma}$ for zircons in a quartz-cordierite gneiss from the south-western part of the Akulleq terrane. Compared with most Archaean rocks of sedimentary origin, the Akulleq quartz-cordierite gneisses have high but variable $\mathrm{SiO}_{2}$, enrichment in $\mathrm{MgO}, \mathrm{FeO}$ and $\mathrm{Al}_{2} \mathrm{O}_{3}$, depletion in $\mathrm{CaO}, \mathrm{Na}_{2} \mathrm{O}$ and $\mathrm{K}_{2} \mathrm{O}$, very high $\mathrm{Zr}, \mathrm{Hf}, \mathrm{Ta}, \mathrm{Nb}$, Th and $\mathrm{U}$, low $\mathrm{Sc}, \mathrm{Cr}, \mathrm{Co}$ and $\mathrm{Ni}$, and enriched and fractionated REE with negative Eu anomalies (Dymek \& Smith 1990). Similar rocks have not been reported from other parts of the Archaean of Greenland south of Disko Bugt. The very unusual chemistry implies a special mode of origin or alteration. Beech \& Chadwick (1980) suggested that the parents of these rocks were mixtures of detrital quartz and precipitated $\mathrm{Mg}$-rich clay minerals, with detrital zircon as the source of the high contents of trace elements. Dymek \& Smith (1990) noted that the quartz-cordierite gneisses have many chemical features in common with felsic igneous rocks and suggested that they were derived from water-lain acid to intermediate volcanic material, possibly mixed with a detrital component of continental provenance, that was affected by intense chemical alteration.

Terrigenous clastic metasediments form moderately thick and homogeneous sequences in several places. Biotite-muscovite-sillimanite-bearing quartzo-feldspathic gneisses in contact with amphibolites on Rypeø near Nuuk were interpreted by Dymek et al. (1983) as derived from sandy, silty and muddy sediments. The trace element chemistry of the rocks suggests derivation from felsic volcanic or plutonic sources (McLennan et al. 1984). SHRIMP dating of euhedral zircons in a single sample gave a semi-continuous range of ${ }^{207} \mathrm{~Pb}-{ }^{206} \mathrm{~Pb}$ ages between 3000 and $2750 \mathrm{Ma}$ (Schiøtte et al. 1988). One arkosic and one pelitic sample gave $\mathrm{T}_{\text {CHUR }}$ model $\mathrm{Sm}-\mathrm{Nd}$ ages of 2660 and $2820 \pm 30 \mathrm{Ma}$ (Hamilton et al. 1983).

Garnet-mica-graphite-bearing gneisses form a thick unit between amphibolites and layered metabasic intrusive rocks on northern Storø. Their trace element chemistry suggests a mixed provenance of mafic volcanics with felsic volcanics and/or tonalitic gneisses (McLennan et al. 1984).

Minor quartzites are present in some supracrustal units, especially adjacent to contacts with early Archaean rocks. Some of these are recrystallised vein quartz formed in fault zones (see below). SHRIMP dating of zircons from a quartzite collected $5 \mathrm{~m}$ from a contact between early Archaean gneisses and supracrustal rocks on Simiutaa at the mouth of Ameralik give a wide range of ${ }^{207} \mathrm{~Pb}-{ }^{206} \mathrm{~Pb}$ ages between 3755 and 2720 $\mathrm{Ma}$, with most euhedrally zoned grains in the ranges $3300-3200$ and $2980-2800$, and rounded unzoned grains mostly between 3200 and 2900 Ma (Schiøtte et al. 1988). These ages do not support the hypothesis that the quartzite is a detrital sediment derived from the adjacent Amitsoq gneisses (Nutman \& Bridgwater 1983), nor do they correspond to known age ranges in the Akia or Tasiusarsuaq terranes. A possible, although somewhat contrived, interpretation is that the quartzite was a sediment derived from all three sources. Zircons from a quartzite unit up to $50 \mathrm{~m}$ thick that can be traced for many kilometres between inner Ameralik and Kapisillit fjord (Friend \& Nutman 1988) have given SHRIMP ages between 3880 and $3650 \mathrm{Ma}$ that correspond closely to known ages ranges in the southern unit of early Archaean rocks (Kinny et al. 1987). This suggests a clastic sediment derived from rocks originally continuous with this unit.

\section{(3) Layered metabasic intrusive rocks}

Meta-anorthosites and meta-leucogabbros, associated with subordinate marginal amphibolites derived from gabbros, and minor olivine-horn- 
blende layers, occur as continuous units and as enclaves in the Ikkattoq gneisses that intrude and migmatise them. Where they are not strongly deformed, the leucogabbros commonly have cumulate megacrystic textures. The association has many similarities to the Fiskenæsset Complex in the Tasiusarsuaq terrane (Myers 1985), although chromitites, a characteristic minor component of the latter, have not been reported in the Akulleq terrane. The layered metabasic rocks are intepreted as derived from one or more large stratiform bodies intruded into the supracrustal rocks. Few intrusive features have survived migmatisation and deformation, and it is not certain which of the supracrustal associations the stratiform bodies were intruded into.

\section{(4) Ikkattoq gneisses}

Quartzo-feldspathic gneisses, the protoliths of which intruded lithological associations (1), (2) and (3), make up between a third and a half of the outcrops in the Akulleq terrane. Until recently few of these had been dated and they were considered to be the same age as the type Nûk gneisses in the eastern part of the Akia terrane (McGregor 1973, 1984, Compton 1978, Coe \& Robertson 1982, 1984, Chadwick \& Coe 1983, Robertson 1986). Conventional zircon dating of gneisses in the Færingehavn - Tre Brødre area in the southern part of the Akulleq terrane suggested that the Ikattoq gneisses were intruded 2800-2750 Ma ago (Nutman et al. 1989). Further SHRIMP dating of samples that span much of the area underlain by Ikkattoq gneisses in the Akulleq terrane has yielded more accurate, concordant ages of 2825-2810 Ma (L. Schiøtte pers. comm., H. Baadsgaard \& A.P. Nutman unpublished data).

The Ikkattoq gneisses are dominantly granodioritic in composition with minor dioritic phases in some areas. Many of them were intruded as sub-concordant sheets, commonly along contacts between the older lithological units. They differ in appearance from the type Nûk gneisses in several ways. They are much more homogeneous in outcrop than the Nûk gneisses, which are commonly polyphase, a feature shared with the majority of the early Archaean Amitsoq grey gneisses and the tonalitic-granodioritic gneisses in the Tasiusarsuaq terrane. The Nûk gneisses, where they are not strongly deformed, usually have speckled textures that are secondary after coarse-grained plutonic textures in the protoliths. Similar textures are not common in the Ikkattoq gneisses, suggesting that their protoliths were finer grained. Ikkattoq gneisses characteristically have widely-spaced, thin pegmatitic layers. These textures and structures suggest that the protoliths of many of the Ikkattoq gneisses were intruded and crystallised syntectonically, with deformation during crystallisation of the magmas inhibiting the growth of large grains and producing primary gneissic foliation and layering, in part defined by thin pegmatites. By contrast, many of the protoliths of the Nûk gneisses appear to have crystallised under static conditions that permitted coarse-grained plutonic textures to develop.

The Ikkattoq gneisses differ compositionally from many other Archaean grey gneiss associations, for example the amphibolite facies Nûk gneisses in the south-eastern part of the Akia terrane (Table 2). Tonalitic compositions are rare or absent in the Ikkattoq gneisses, but are the most abundant lithology in the Nûk gneisses. The Ikkattoq dioritic gneisses have $\mathrm{SiO}_{2}$ contents in the range $55-64 \%$ which is not represented in the Nûk gneisses. Ikkattoq granodioritic gneisses are richer in $\mathrm{Fe}, \mathrm{K}, \mathrm{Rb}, \mathrm{Y}, \mathrm{Zr}$ and $\mathrm{Nb}$, and considerably poorer in $\mathrm{Na}, \mathrm{Sr}$ and $\mathrm{Cr}$ than Nûk granodioritic gneisses with similar $\mathrm{SiO}_{2}$ contents.

Ikkattoq-like gneisses from an area within the Akulleq terrane in inner Godthåbsfjord have given a Rb-Sr whole-rock isochron date of $2767 \pm 40$ Ma with $\mathrm{Sr}_{i}=0.7022 \pm 0.0006$, and a $\mathrm{Pb}-\mathrm{Pb}$ whole-rock isochron date of $2962 \pm 73 \mathrm{Ma}$ with an apparent single-stage $\mu$ value of $6.64 \pm 0.05$ (Robertson 1983, 1986). Comparison with zircon ages of Ikkattoq gneisses elsewhere in the Akulleq terrane suggests that the older $\mathrm{Pb}-\mathrm{Pb}$ date and the low apparent single-stage $\mu$ are the result of contamination with $\mathrm{Pb}$ from early Archaean crust. Samples of probable Ikkattoq gneisses studied by Taylor et al. (1980) have Pb characteristics that indicate contamination with early Archaean crustal $\mathrm{Pb}$. Sm-Nd characteristics of the Ikkattoq gneisses also indicate involvement of early Archaean sialic material (H. Baadsgaard, pers. comm.). 


\section{Relations between lithological associations in the Akulleq terrane}

Intense deformation and the intrusion of Ikkattoq gneisses along many contacts have destroyed most evidence of the original relations between the early Archaean rocks and the supracrustal units that are interleaved with them. There is good field evidence that at least some of the contacts are tectonic (McGregor 1973, 1975, Chadwick \& Nutman 1979, Hall \& Friend 1979). Contacts considered to be deformed unconformities were described on Qilanngaarsuit by Chadwick \& Nutman (1979) and on Simiutaa by Nutman \& Bridgwater (1983). Re-examination of the contact on the west coast of Qilanngaarsuit indicates that it, too, is tectonic. In a low deformation area near the core of a fold, $5-10 \mathrm{~m}$ of blastomylonite interlayered with very finegrained greenish quartzite separate supracrustal amphibolites from Amîtsoq gneisses that adjacent to the mylonite are strongly sheared and contain clots of green mica. Along the same contact on nearby fold limbs, where deformation was more intense, the mylonites have been strongly thinned or completely cut out and the amphibolites are now separated from Amîtsoq gneisses by thin layers of micaceous rocks or by quartzites, or are in sharp contact with the Amitsoq gneissès. Relations along the amphibolite-Amîtsoq gneiss contacts on Simiutaa are more ambiguous, but there is no unequivocal evidence of an unconformity. Some of the quartzites adjacent to the contact appear to be silicified Amîtsoq gneisses. Quartzite lenses immediately along the contact are similar to the quartzites within the blastomylonites on western Qilanngaarsuit. The ages of zircons from the quartzite studied by Kinny et al. (1988) show that this was a detrital sediment derived from early Archaean continental rocks like those in the southern unit of the Akulleq terrane. The composition of the rock indicates a very mature sediment that is likely to have been lain down on or immediately adjacent to the early Archaean continent. Thus while some of the metasedimentary rocks in the Akulleq terrane may well have been laid down on early Archaean rocks, there is no evidence that the amphibolites, the quartz-cordierite gneisses and the layered basic intrusives formed a cover sequence on an early Archaean basement. It is quite likely that they are slices of oceanic crust that were interleaved tectonically with the early Archaean rocks. There is local evidence of tectonic interleaving within the supracrustal sequence, for example imbrication of quartz-cordierite gneisses and layered basic intrusive rocks on Quersuaq, south-west of Qilanngaarsuit.

Tectonic contacts with blastomylonites between units of early Archaean rocks and of Ikkattoq gneisses with enclosed supracrustal and layered basic intrusive rocks in the Færingehavn Tre Brødre area led Friend et al. (1987) to separate these units into the Færingehavn and Tre Brødre terranes respectively. However in several parts of the Akulleq terrane Ikkattog gneisses clearly intrude early Archaean rocks. In the Færingehavn - Tre Brødre area itself there are small areas of early Archaean rocks intruded by Ikkattoq gneisses within the Tre Brødre terrane. In outer Ameralik and Kobbefjord the type Amitsoq gneisses are clearly intruded by sheets of Ikkattoq gneiss of all sizes. A possible explanation of these relations is that intrusion of the Ikkattoq magmas overlapped in time with tectonic interleaving. Ikkattoq magmas appear commonly to have been intruded along thrust planes between and within the older lithological units during or after interleaving. Locally, as in the Færingehavn - Tre Brødre area, there was tectonic interleaving after the intrusion of the Ikkattoq magmas.

\section{Tectonic boundaries of the Akulleq terrane}

The boundary of the Akulleq terrane to the south-east is the Qarliit nunaat thrust, along which rocks of the Tasiusarsuaq terrane that are retrogressed from granulite facies or that have relict granulite facies assemblages, overlie rocks of the Akulleq terrane that have never been in granulite facies. As noted above, the Tasiusarsuaq terrane appears to show a tilted section of the crust with progressively deeper levels exposed from south-east to north-west towards the thrust. The sinuous trace of the thrust reflects the fact that it was folded by NNE-trending upright folds (F2 in the terminology of Friend et al. 1988b). To the south-west the thrust is strongly modified within zones of intense ductile deforma- 
tion, has been rotated to an almost vertical position, and is difficult to locate precisely. It is less deformed to the east, south of inner Ameralik, where an amphibolite facies fabric adjacent to the thrust and parallel to it can still be seen (Friend et al. 1988a, figs 2 and 3).

The boundary of the Akulleq terrane to the north-west, the Ivinnguit fault, is less modified than the Qarliit nunaat thrust and is presumably younger. The fault is nearly straight and does not appear to be folded by F2. In the south and on northern Stor $\varnothing$ it lies within late zones of strong ductile deformation and is almost vertical or dips steeply to the east (Friend et al. 1988b, fig. 2). On Sadel $\emptyset$ and the south-east corner of Bjørneøen the fault dips at moderate angles to west-northwest, is more or less parallel to the structure in the rocks on each side and has a well preserved blastomylonite zone $10-20 \mathrm{~m}$ thick. Much of the trace of the fault to the north as far as Ilulialik lies under Godthåbsfjord or is obscured by Quaternary deposits. The lowest metamorphic grade and therefore presumably the highest crustal level in the Akia terrane crops out adjacent to the fault on Sadelø and Bjørneøen, where the rocks were never metamorphosed above middle amphibolite facies. This is the opposite of the situation in the Tasiusarsuaq terrane above the Qarliit nunaat thrust.

\section{Late Archaean history of the Godthåbsfjord region}

The rocks of the Akulleq terrane were affected by several episodes of deformation. The earliest that affected all major units (except for late granites) produced major tight to isoclinal folds (F1) that in the less deformed, eastern part of the terrane trend approximately east-west, are overturned towards the north, and are asymmetric, with parts of the lower limbs commonly removed by shear zones (Friend \& Nutman 1988, Nutman et al. 1989). The southern unit of early Archaean rocks forms the core of a major, north-west-facing nappe enclosed by Ikkattoq gneisses (Friend et al. 1988b, fig. 2). F1 folds do not affect the Qarliit nunaat thrust, but both are manifestations of tectonic transport towards the north-west and they may be related. The F1 isoclines are refolded by upright, north-east-trending folds (F2) that also fold the Qarliit nunaat thrust. The Ivinnguit fault does not appear to have been folded by $F 2$ and is parallel to F2 axial traces. The amplitude of the $\mathrm{F} 2$ folds decreases away from the fault, and this led Friend et al. (1988b) to suggest that the $\mathrm{F} 2$ folds could be the result of docking of the Akia terrane against the alreadyjuxtaposed Akulleq and Tasiusarsuaq terranes.

The timing of accretion of the Tasiusarsuaq, Akulleq and Akia terranes is not well constrained. Both the Qarliit nunaat thrust and the Ivinnguit fault cut Ikkattoq gneisses and this sets an older limit of ca. $2800 \mathrm{Ma}$. A younger limit is given by late granites that cut all terranes and that give dates between ca. 2700 and $2500 \mathrm{Ma}$, with a peak at ca. $2530 \mathrm{Ma}$ when the Qôrqut granite complex formed (Baadsgaard 1976, Brown et al. 1981, Moorbath et al. 1981, Robertson 1983, McGregor et al. 1983, Friend et al. 1985). High initial strontium isotope ratios and other chemical features indicate that these granites are the products of crustal melting that involved an early Archaean component in the source region. Airborne gamma-spectrometer measurements (Secher \& Steenfelt 1981, see McGregor et al. 1986, fig. 9) show that the Akulleq terrane has high levels of $\mathrm{K}, \mathrm{U}$ and $\mathrm{Th}$, particularly the southern unit of early Archaean rocks and the Qôrqut granite complex. The late peak of granite generation and the fact that the Qôrqut granite complex is made up of a very large number of discrete, gently-dipping sheets of granite and pegmatite suggest slow radioactive heating of the Akulleq terrane following overthrusting by the Tasiusarsuaq and Akia terranes, with segregation of small batches of magma that rose individually to higher crustal levels.

Late within the period of generation of the granites a NNE-SSW-trending zone of strong ductile deformation that crosses all three terranes was formed under amphibolite facies conditions. A straight belt of intense ductile deformation extends continuously from some distance north of the head of Fiskefjord (Garde et al. 1983) south along the west side of Qussuk, where it is ca. $4 \mathrm{~km}$ wide, through the south-western parts of Bjørneøen and Sadel $\varnothing$, the Nuuk peninsula and the islands to the south. Within this belt the lithological units are streaked out, more or less parallel, and have a regular steeply-dipping layering parallel to the trend of the belt. A strong linear 
fabric element that plunges $20-30^{\circ}$ to southsouth-west appears to be mainly the result of rotation of earlier structures. A similar belt of intense ductile deformation ca. $5 \mathrm{~km}$ wide extends through the outer parts of Buksefjorden and Færingehavn fjord. Between these two belts earlier structures have been tightened but not streaked out as in the straight belts, folds have acquired sheath forms, and there is commonly a very strong linear fabric parallel to that in the straight belts (Chadwick \& Nutman 1979), indicating strong stretching with less flattening than in the straight belts. There are smaller zones of strong late ductile deformation outside the main zone and lacunae of low deformation within it. The overall effect of the late deformation zone is a narrowing and anticlockwise rotation of the Akulleq terrane in the south-western part of the region. The zone may be a deeper, ductile section of a transcurrent fault zone across which there was also vertical displacement with relative upthrow to the west.

Where the line of the Qôrqut granite complex intersects the late deformation zone there are abundant deformed pegmatite-granite sheets, the Sâtut gneisses of Nutman et al. (1989). Recent SHRIMP dating of the Sãtut gneisses confirms the original correlation with the Qôrqut granite complex (Chadwick \& Coe 1983) and suggests that formation of the complex mainly predated the late deformation zone. Scattered undeformed granite sheets within the western straight belt on the Nuuk peninsula show that granite generation outlasted deformation.

\section{Correlation with northern Labrador}

The Saglek-Hebron-Okak region of northern Labrador is made up of early Archaean rocks, the Uivak gneisses and Nulliak supracrustal rocks, interleaved with larger, more continuous units of Upernavik supracrustal rocks (see Bridgwater \& Schiøtte 1991 (this volume) for references). The Saglek-Okak region is approximately along the line of the Akulleq terrane in a pre-drift reconstruction of Greenland and North America, although apparently displaced a little to the north (Fig. 2). The early Archaean rocks in the southwestern part of the Akulleq terrane, between the mouth of Ameralik and Tre Brødre, have more in common with the early Archaean rocks of the Saglek area than with those in the Isukasia area in the north-eastern part of the Akulleq terrane. For example, the Fe-rich Uivak II gneisses are virtually identical to the Fe-rich suite of augen and ferrodioritic gneisses in the Amitsoq gneisses (Nutman et al. 1984). It is likely that the Uivak gneisses in the Saglek area are part of the same block of early Archaean continental crust as the southern unit of Amîtsoq gneisses in the Akulleq terrane. In Labrador the extent of the early Archaean rocks is not as well established as in West Greenland. Early Archaean rocks occur over a distance of at least $200 \mathrm{~km}$ along the coast. They strike approximately north-south, oblique to the trend of the Akulleq terrane in West Greenland. No major tectonic boundaries equivalent to the Qarliit nunaat thrust or the Ivinnguit fault have been recognised.

A major difference between the Saglek-Okak region and the Akulleq terrane is the absence or scarcity in the former of rocks equivalent to the Ikkattoq gneisses. However, the proportion of Ikkattoq gneisses to other rocks decreases considerably along and across the Akulleq terrane from north-east to south-west, in the direction of Labrador. Over much of the Saglek-Okak region the early (?-mid) Archaean rocks were affected by granulite facies metamorphism accompanied by partial melting and mobilisation in a complex interplay of partly decoupled processes within the period 2770-2710 Ma (Schiøtte et al. 1989b). This may well prove to overlap with the period when the Tasiusarsuaq, Akulleq and Akia terranes were juxtaposed. Many of the differences in the geology along the Akulleq terrane may be explained in terms of differences in crustal level, with the shallowest level exposed in the Isukasia area to the north-east, progressively deeper levels exposed towards the south-west in West Greenland, and an even deeper level, again becoming deeper towards south and west, in northern Labrador. Comparison with the Akulleq terrane in West Greenland suggests that the cause of granulite facies metamorphism in the SaglekOkak region may have been a combination of crustal thickening and magmatic heating. 


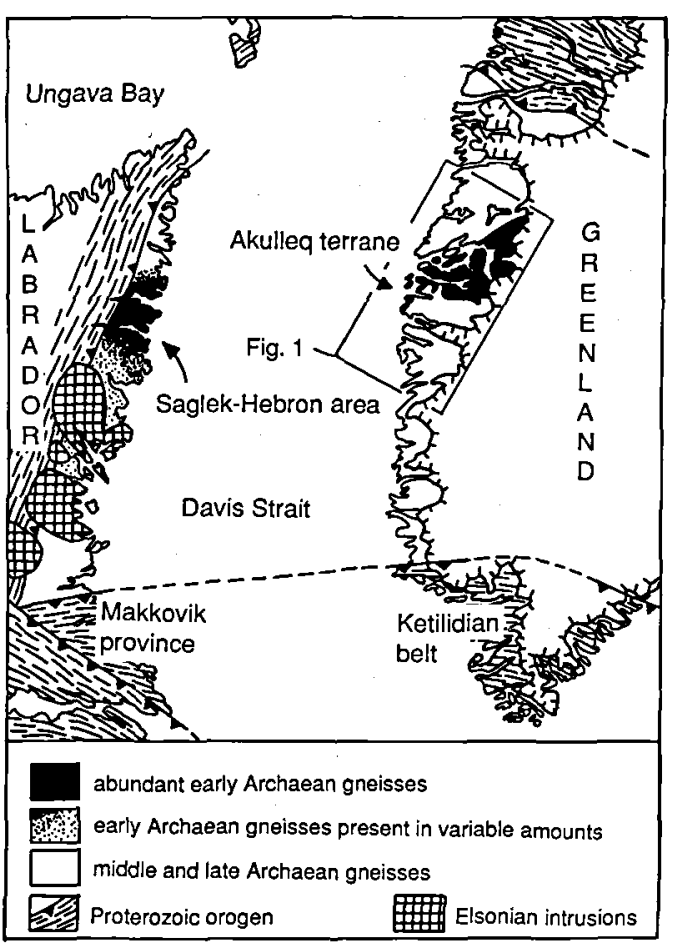

Fig. 2. Map showing the position of the Godthabsfjord region relative to the Saglek-Hebron area of Labrador prior to the opening of the Labrador Sea.

\section{Significance of the Godthåbsfjord belt}

It has been shown in the foregoing that the Akulleq terrane is a belt of rocks of very varied ages and origins that is separated by major tectonic breaks from more extensive blocks of middle and late Archaean rocks on each side, and that it has few if any lithological units in common with these blocks. It has also been shown that although there are many similarities between the blocks on either side of the Akulleq terrane, they are in fact made up of rocks with different primary ages and different metamorphic histories.

A plausible explanation of this relationship is that the blocks on either side of the Akulleq terrane were parts of two separate continental masses and that the Akulleq terrane is made up of rocks from different parts of the crust originally separating the two continents that were interleaved and welded together in the late Archaean as a result of the approach and collision of the continents (Fig. 3). In this model the early Archaean rocks are interpeted as fragments of early continental crust that were caught between the mid-late Archaean continents. The amphibolites in the Akulleq terrane may be remnants of oceanic crust that were not subducted because they were tectonically intercalated with buoyant early Archaean sialic rocks. The quartzo-feldspathic metasediments could be derived from detrital sediments eroded from either of the midlate Archaean continents, from the early Archaean continental crust, from felsic volcanics associated with subduction, or from mixed sources. The Ikkattoq gneisses may have been subduction-related magmas that were intruded syntectonically into the pile of thrust slices above the subduction zone. The dominantly granodioritic composition of the Ikkattoq gneisses, the field evidence that they intruded early Archaean rocks, and the isotopic evidence of involvement of early Archaean rocks in their genesis suggest a subduction zone descending beneath the early Archaean continent with mixing of subductionderived magmas with magmas produced by melting of the deeper parts of the continental crust. The quartz-cordierite gneisses could be derived from volcanic phases of the Ikkattoq magmas that were erupted adjacent to a body of water in which they settled and were subject to intense leaching. Overlapping of the ages of the Ilivertalik granite suite and the granulite facies metamorphism in the Tasiusarsuaq terrane with the ages of the Ikkattoq gneisses in the Akulleq terrane suggest the possibility that this plutonic activity in the Tasiusarsuaq terrane was related in some way to subduction, perhaps underplating by basic magmas of the leading edge of the southern continent, melting of the base of the crust, and mixing of magmas to form the Ilivertalik suite.

In the model suggested here the rocks that now make up the Akulleq terrane were gathered up in front of the continent of which the Tasiusarsuaq terrane is part, and overridden by it. Subsequently the continent of which the Akia terrane is part collided with the composite Akulleq-Tasiusarsuaq block. Deformation of the southern continent accompanied by influx of fluids that caused extensive retrogression of the granulite facies rocks extended at least $60 \mathrm{~km}$ into the Tasiusarsuaq terrane. Deformation and associated retrogression were less extensive in the northern continent. Rocks in the Akulleq terrane that were rich in potassium and other radioactive elements were pushed down by the overriding 


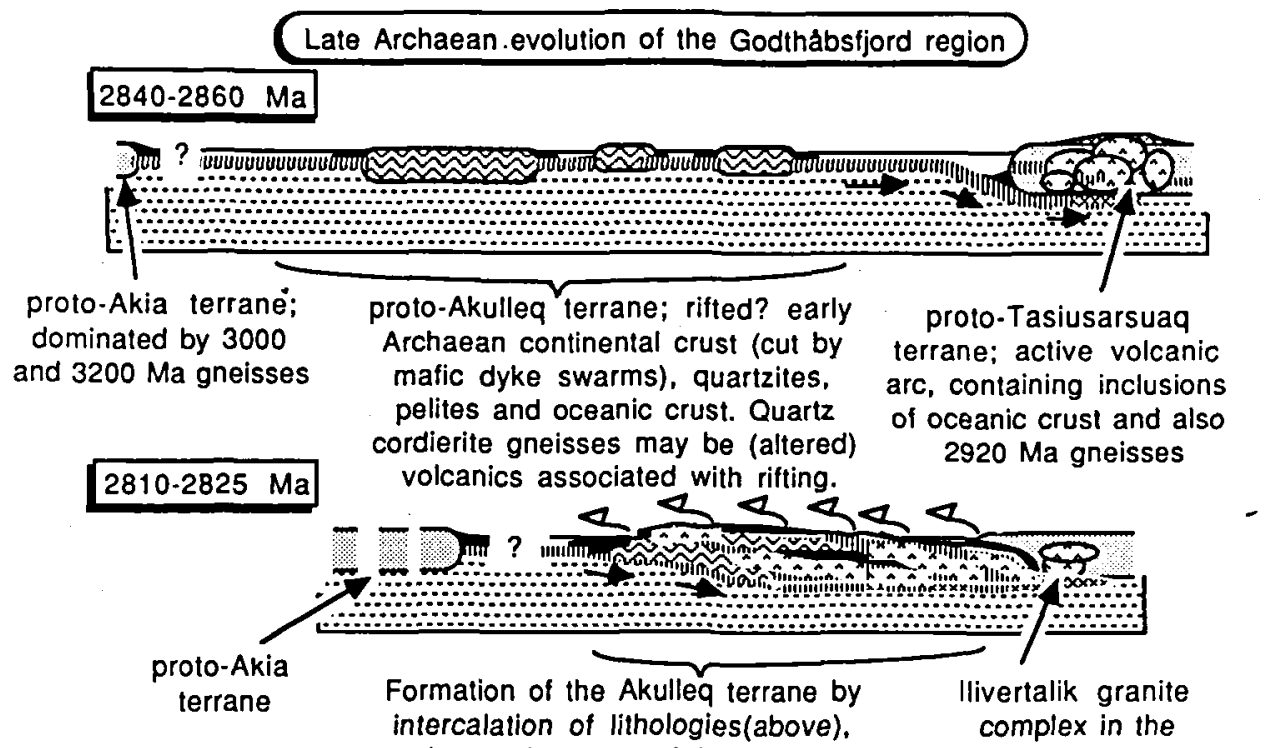

intercalation of lithologies(above). complex in the and the emplacement of the syntectonic Tasiusarsuaq terrane Ikkattoq gneisses. Quartz cordierite gneisses may be volcanic equivalents

\section{$2700-2720 \mathrm{Ma}$}

(altered) of the Ikkattoq gneisses

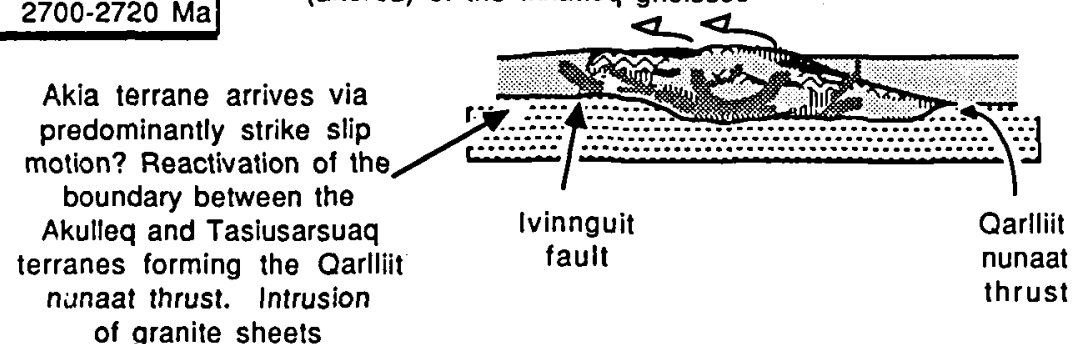

$$
2700-2490 \mathrm{Ma}
$$

Sporadic deformation and emplacement of granitic bodies (e.g. $2550 \mathrm{Ma}$ Qôrqut granite complex), with cooling and erosion of tectonically thickened crust.

Fig. 3. Schematic representation of the late Archaean evolution of the Godthåbsfjord region as proposed in this paper.

blocks on either side. Crustal melting that produced granites took place over a period of 150 Ma or more, but peaked more than $100 \mathrm{Ma}$ after the collision.

The formation of the Godthåbsfjord belt in the late Archaean involved processes different from those that formed the older continental crust of the blocks on either side and the early Archaean continent. Formation of the Amitsoq grey gneisses at ca. $3700 \mathrm{Ma}$, of the tonalitic gneisses in the Akia terrane at ca. $3000 \mathrm{Ma}$ and of the gneisses of the Tasiusarsuaq terrane at ca. 2860 Ma represent the intrusion of enormous volumes of dominantly tonalitic magmas into sequences of extrusive and intrusive basic rocks. The great volumes of tonalitic magmas produced within short periods ( $\leq 100 \mathrm{Ma}$ ), the chemistry and field relations of the basic rocks, and the lack of evidence of involvement of older continental crust suggest intra-oceanic subduction environments. However, the rocks are very different from those of island arcs produced by present-day intraoceanic subduction. Consideration of the chemistry of the calc-alkaline intrusives (Martin 1986), modelling of thermal evolution (Arkani-Hamed \& Jolly 1989), and melting studies (Winther \& Newton 1991 - this volume), all suggest that the tonalitic-trondhjemitic-granodioritic rocks that 
dominate typical Archaean continental crust like the Akia and Tasiusarsuaq terranes were produced by melting of hydrous, low-K tholeiites in descending slabs of oceanic crust. This crust was probably shorter-lived, hotter; and less dense than in present-day island arc subduction zones, and may have underplated the lithosphere rather than have been subducted deep into the mantle (Arkani-Hamed \& Jolly op. cit.). The Godthåbsfjord belt shows a different tectonic style that involved older continental crust in addition to oceanic crust. At the stage when the Ikkattoq gneisses were formed it had features in common with active continental margins, while during later stages when the three terranes were juxtaposed it had more in common with mobile belts resulting from continent-continent collisions.

Acknowledgements. We thank Dansk Geologisk Forening (the Geological Society of Denmark) for providing the three of us with the opportunity to meet again and discuss our developing ideas, Grønlands Geologiske Undersøgelse for invaluable support throughout the years we have worked in Greenland, and H. Baadsgaard, P. Kinny and F. Kalsbeek for permission to quote unpublished results. VRM thanks Dansk Geologisk Forening for the honour accorded to him in the award of the Steno Medal, Carlsbergfondet for generous support for his field work since 1985, the Danish Natural Science Research Council for the grant that allowed him to travel from Greenland to Europe, and the many people in West Greenland, especially in Atammik, who have helped him during the 25 years he has worked there. CRLF acknowledges financial support from the Royal Society and Oxford Polytechnic.

\section{Dansk sammendrag}

I Godthåbsfjord-regionen i det sydlige Vestgrønland findes et N $\varnothing-S V$-gående bælte, der består af bjergarter med varierende alder og oprindelse. Dette balte, som i nærværende artikel kaldes 'Akulleq terrane', er begrænset af vigtige forkastninger mod to større blokke af typiske højmetamorfe Arkæiske bjergarter, der på trods af mange ligheder har forskellige aldre og metamorfe udviklingshistorier. Den kontinentale skorpe, som danner blokken mod nordvest (kaldet 'Akia terrane') blev dannet for mellem ca. $3200 \mathrm{og} 2980$ mill. år siden, hvorimod den sydøstlige blok ('Tasiusarsuaq terrane') dannedes for ca. 2800 2650 mill. år siden. Bjergarterne i Akulleq terrane tolkes som forskellige skorpefragmenter, som oprindeligt adskilte de to større blokke, og som omfatter tidlig Arkæisk kontinental skorpe, mulig oceanskorpe og sure til intermediære intrusive og måske også ekstrusive magmabjergarter, som kan være dannet under subduktionslignende omstændigheder.

\section{References}

Appel, P. W. U. 1988: Scheelite in the Malene supracrustals of the Ivisârtoq area, southern West Greenland. Rapp. Grønlands geol. Unders. 140, 57-58.
Appel, P. W. U. \& Garde, A. A. 1987: Stratabound scheelite and stratiform tourmalinites in the Archaean Malene supracrustal rocks, southern West Greenland. Bull. Grønlands geol. Unders. 156, $26 \mathrm{pp}$.

Arkani-Hamed, J. \& Jolly, W. T. 1989: Generation of Archean tonalites. Geology 17, 307-310.

Ashwal, L. D., Jacobsen, S. B., Myers, J. S., Kalsbeek, F. \& Goldstein, S. J. 1989: Sm-Nd age of the Fiskenæsset Anorthosite Complex, West Greenland. Earth planet. Sci. Lett. 91, 261-270.

Baadsgaard, H. 1976: Further U-Pb dates on zircons from the early Precambrian rocks of the Godthaabsfjord area, West Greenland. Earth planet. Sci. Lett. 33, 261-267.

Baadsgaard, H. \& McGregor, V. R. 1981: The U-Th-Pb systematics of zircons from the type Nûk gneisses, Godthåbsfjord, West Greenland. Geochim. Cosmochim. Acta 45, 1099-1109.

Baadsgaard, H., Nutman, A. P., Bridgwater, D., Rosing, M., McGregor, V. R. \& Allaart, J. H. 1984: The zircon geochronology of the Akilia association and Isua supracrustal belt, West Greenland. Earth planet. Sci. Lett. 68, 221-228.

Baadsgaard, H., Nutman, A. P. \& Bridgwater, D. 1986: Geochronology and isotopic variation of the early Archaean Amitsoq gneisses of the Isukasia area, southern West Greenland. Geochim. Cosmochim. Acta 50, 2173-2183.

Beech, E. M. \& Chadwick, B. 1980: The Malene supracrustal gneisses of northwest Buksefjorden: their origin and significance in the Archaean crustal evolution of southern West Greenland. Precambrian Res. 11, 392-355.

Berthelsen, A. 1962: Structural studies in the pre-Cambrian of western Greenland; part III: Southern Sukkertoppen district. Meddr Grønland 123(2), $47 \mathrm{pp}$.

Brown, M., Friend, C. R. L., McGregor, V. R. \& Perkins, W. T. 1981: The late Archaean Qôrqut granite complex of southern West Greenland. J. geophys. Res. 86, 1061710632.

Chadwick, B. 1981: Field relations, petrography and geochemistry of Archaean amphibolite dykes and Malene supracrustal amphibolites, northwest Buksefjorden, southern West Greenland. Precambrian Res. 14, 221-259.

Chadwick, B. 1990: The stratigraphy of a sheet of supracrustal rocks within high-grade orthogneisses and its bearing on Late Archaean structure in southern West Greenland. $J$. geol. Soc. Lond. 147, 639-652.

Chadwick, B. \& Coe, K. 1983: Descriptive text to 1:100 000 sheet Bukesfjorden 63 V.1 Nord. Copenhagen: Grønlands geol. Unders., 70 pp.

Chadwick, B. \& Nutman, A. P. 1979: Archaean structural evolution in the northwest of the Buksefjorden region, southern West Greenland. Precambrian Res. 9, 199-226.

Coe, K. \& Robertson, S. 1982: Mapping of Archaean rocks in part of the Ivisârtoq sheet. Rapp. Grọnlands geol. Unders. $110,63-67$.

Coe, K. \& Robertson, S. 1984: Contrasting styles of Archaean crustal evolution in parts of southern West Greenland. $J$. Geodynamics 1, 301-311.

Collerson, K. D., McCulloch, M. T. \& Nutman, A. P. 1989: Sr and $\mathrm{Nd}$ isotope systematics of polymetamorphic Archean gneisses from southern West Greenland and northern Labrador. Can. J. Earth Sci. 26, 446-466.

Compston, W., Kinny, P. D., Williams, I. S. \& Foster, J. J. 1986: The age and $\mathrm{Pb}$ loss behaviour of zircons from the Isua supracrustal belt as determined by ion microprobe. Earth planet. Sci. Lett. 80, 71-81.

Compton, P. 1978: Rare earth evidence for the origin of the Nûk gneisses Buskefjorden region, southern West Greenland. Contrib. Mineral. Petrol. 66, 283-293.

Dymek, R. F. \& Smith, M. S. 1990: Geochemistry and origin of Archaean quartz-cordierite gneisses from the Godthåbs- 
fjord region, West Greenland. Contrib. Mineral. Petrol. $105,715-730$.

Dymek, R. F., Weed, R. \& Gromet, L. P. 1983: The Malene metasedimentary rocks on Rypeø and their relationship to Amitsoq gneisses. Rapp. Gronlands geol. Unders. 112, 53-69.

Friend, C. R. L. \& Nutman, A. P. 1988: Evolution and emplacement of Archaean terranes in the Kapisigdlit area, southern West Greenland. Rapp. Grønlands geol. Unders. $140,59-64$.

Friend, C. R. L., Brown, M., Perkins, W. T. \& Burwell, A. D. M. 1985: The geology of the Qorqut granite complex north of Qôrqut, Godthåbsfjord, southern West Greenland. Bull. Gronlands geol. Unders. 151, $43 \mathrm{pp}$.

Friend, C. R. L., Nutman, A. P. \& McGregor, V. R. 1987: Late-Archaean tectonics in the Frringehavn-Tre Brødre area, south of Buksefjorden, southern West Greenland. J. geol. Soc. Lond. 144, 369-376.

Friend, C. R. L., Nutman, A. P. \& McGregor, V.R. 1988a: Significance of the late Archaean granulite facies terrain boundaries, southern West Greenland. In Ashwal, L. D. (ed.) Workshop on the deep continental crust of South India, Lunar planet Inst. tech. Rep. 88-06, 46-48.

Friend, C. R. L., Nutman, A. P. \& McGregor, V. R. 1988b: Late Archaean terrane accretion in the Godthåb region, southern West Greenland. Nature 335, 535-538.

Garde, A. A. 1989: Retrogression and fluid movement across a granulite-amphibolite facies boundary in middle Archaean Nûk gneisses, Fiskefjord, southern West Greenland. In Bridgwater, D. (ed.) Fluid movements - element transport and the composition of the deep crust., 125-137. Dordrecht: Kluwer.

Garde, A. A. 1990: Thermal granulite-facies metamorphism with diffuse retrogression in Archaean orthogneisses, Fiskefjord, southern West Greenland. J. metamorphic Geol. $8,663-682$.

Garde, A. A., Hall, R. P., Hughes, D. J., Jensen, S. B., Nutman, A. P. \& Stecher, O. 1983: Mapping of the Isukasia map sheet, southern West Greenland. Rapp. Grønlands geol. Unders. 115, 20-29.

Garde, A. A., Larsen, O. \& Nutman, A. P. 1986: Dating of late Archaean crustal mobilisation north of Qugssuk, Godthåbsfjord, southern West Greenland. Rapp. Gronlands geol. Unders. 128, 23-36.

Gill, R. C. O. \& Bridgwater, D. 1976: The Ameralik dykes of West Greenland, the earliest known basaltic rocks intruding stable continental crust. Earth planet. Sci. Lett. 29, 276-282.

Griffin, W. L., McGregor, V. R., Nutman, A., Taylor, P. N. \& Bridgwater, D. 1980: Early Archaean granulite-facies metamorphism south of Ameralik, West Greenland. Earth planet. Sci. Lett. 50, 59-74.

Hall, R. P. 1980: The tholeiitic and komatiitic affinities of the Malene metavolcanic amphibolites from Ivisârtoq, southern West Greenland. Rapp. Grønlands geol. Unders. 97, $20 \mathrm{pp}$.

Hall, R. P. \& Friend, C. R. L. 1979: Structural evolution of the Archean rocks in Ivisârtoq and the neighboring inner Godthåbsfjord region, southern West Greenland. Geology 7, 311-315.

Hall, R. P., Hughes, D. J. \& Friend, C. R. L. 1987: MidArchaean basic magmatism of southern West Greenland. In Park, R. G. \& Tarney, J. (eds) Evolution of the Lewisian and comparable Precambrian high grade terrains. Spec. Publ. geol. Soc. Lond. 27, 261-275.

Hamilton, P. J., O'Nions, R. K., Bridgwater, D. \& Nutman, A. 1983: Sm-Nd studies of Archaean metasediments and metavolcanics from West Greenland and their implications for the Earth's early history. Earth planet. Sci. Lett. 62, 263-272.
Harland, W. B., Cox, A., Llewellyn, P. G., Pickton, C. A. G. Smith, A. G. \& Walters, R. 1982: A geologic time scale. Cambridge Univ. Press.

Jones, N. W., Moorbath, S. \& Taylor, P. N. 1986: Age and origin of gneisses south of Ameralik, between Kangimutsangmissoq and Qasigianguit. In Ashwal, L. D. (ed.) Workshop on early crustal genesis: the world's oldest rocks. Lunar planet. Inst. tech. Rep. 88-04, 59-62.

Kalsbeek, F. \& Garde, A. A. 1989: Descriptive text to 1:500 000 sheet 2, Frederikshab Isblink - Søndre Strømfjord. 36 pp. Copenhagen: Grønlands geol. Unders.

Kinny, P. D. 1986: 3820 Ma zircons from a tonalitic Amitsoq gneiss in the Godthåb district of southern West Greenland. Earth planet. Sci. Lett. 79, 337-347.

Kinny, P. D. 1987: Uranium-lead and hafnium isotopes in zircon. Unpubl. Ph.D. thesis, Australian National University, Canberra. $160 \mathrm{pp}$.

Kinny, P. D., Compston, W. \& McGregor, V.R. 1988: The early Archaean crustal history of West Greenland as recorded by detrital zircons. In Ashwal, L. D. (ed.) Workshop on the growth of continental crust. Lunar planet. Inst. tech. Rep. 88-02, 79-81.

Marker, M. \& Garde, A. A. 1988: Border relations between the amphibolite facies Finnefjeld gneiss complex and granulite facies grey gneisses in the Fiskefjord area, southern West Greenland. Rapp. Grønlands geol. Unders. 140 , 49-54.

Martin, H. 1986: Effect of steeper Archean gradient on geochemistry on subduction-zone magmas. Geology 14, 753-756.

McGregor, V. R. 1969: Early Precambrian geology of the Godthåb area. Rapp. Gronlands geol. Unders. 19, 28-30.

McGregor, V. R. 1973: The early Precambrian gneisses of the Godthåb district, West Greenland. Phil. Trans. R. Soc. London A 273, 343-358.

McGregor, V. R., 1975: A horizontal tectonic regime in the Archaean of Greenland and its implications for early crustal thickening - a reply. Precambrian Res. 2, 400-404.

McGregor, V. R. 1979: Archean gray gneisses and the origin of the continental crust: evidence from the Godthåb region, West Greenland. In Barker, F. (ed.) Trondhjemites, da cites, and related rocks, 169-204. Amsterdam: Elsevier.

McGregor, V. R. (compiler) 1984: Geological map of Greenland 1:100 000, Qôrqut 64 V.1 Syd. Copenhagen: Geol. Surv. Greenland.

McGregor, V. R. \& Mason, B. 1977: Petrogenesis and geochemistry of metabasaltic and metasedimentary enclaves in the Amitsoq gneisses, West Greenland. Am. Mineral. 62, 887-904.

McGregor, V. R., Bridgwater, D. \& Nutman, A. P. 1983: The Qârusuk dykes: post-Nûk, pre-Qôrqut granitoid magmatism in the Godthåb region, southern West Greenland. Rapp. Grønlands geol. Unders. 112, 101-112.

McGregor, V. R., Nutman, A. P. \& Friend, C. R. L. 1986: The Archean geology of the Godthåbsfjord region, southern West Greenland. In Ashwal, L. D. (ed.) Workshop on early crustal genesis: the world's oldest rocks. Lunar planet. Inst. tech. Rep. 86-04, 113-169.

McLennan, S. M., Taylor, S. R. \& McGregor, V. R. 1984: Geochemistry of Archean metasedimentary rocks from West Greenland. Geochim. Cosmochim. Acta 48, 1-13.

Moorbath, S., Taylor, P. N. \& Goodwin, R. 1981: Origin of granitic magma by crustal remobilisation: $\mathrm{Rb}-\mathrm{Sr}$ and $\mathrm{Pb} / \mathrm{Pb}$ geochronology of the late Archaean Qôrqut Granite Complex of southern West Greenland. Geochim. Cosmochim. Acta 45, 1051-1060.

Myers, J. S. 1976: Acid and intermediate intrusions, deformation and gneiss formation, north-east of Fiskenæsset. Rapp. Grønlands geol. Unders. 73, 7-15.

Myers, J. S. 1981: The Fiskenaesset Anorthosite Complex - a stratigraphic key to the tectonic evolution of the West 
Greenland gneiss complex 3000-2800 m.y. ago. Spec. Publ. geol. Soc. Aust. 7, 351-360.

Myers, J. S. 1985: Stratigraphy and structure of the Fiskenesset Complex, southern West Greenland. Bull. Gronlands geol. Unders. 150, $72 \mathrm{pp}$.

Nutman, A. P. 1986: The early Archaean to Proterozic history of the Isukasia area, southern West Greenland. Bull. Grønlands geol. Unders. 154, $80 \mathrm{pp}$.

Nutman, A. P. \& Bridgwater, D. 1983: Deposition of Malene supracrustal rocks on an Amîtsoq basement in outer Ameralik, southern West Greenland. Rapp. Gronlands geol. Unders. 112, 43-51.

Nutman, A. P. \& Friend, C. R. L. 1989: Reappraisal of crustal evolution at Kangimut sammisoq, Ameralik fjord, southern West Greenland: fluid movement and interpretation of $\mathrm{Pb} / \mathrm{Pb}$ isotopic data. In Bridgwater, D. (ed.) Fluid movements - element transport and the composition of the deep crust, 319-329. Dordrecht: Kluwer.

Nutman, A. P., Bridgwater, D., Dimroth, E., Gill, R. C. O. \& Rosing, M. 1983: Early ( $3700 \mathrm{Ma}$ ) Archaean rocks of the Isua supracrustal belt and adjacent gneisses. Rapp. Gronlands geol. Unders. 112, 5-22.

Nutman, A. P., Bridgwater, D. \& Fryer, B. J. 1984: The iron-rich suite from the Amitsoq gneisses of southern West Greenland: early Archaean plutonic rocks of mixed crustal and mantle origin. Contr. Mineral. Petrol. 87, 24-34.

Nutman, A. P., Friend, C. R. L., Baadsgaard, H. \& McGregor, V. R. 1989: Evolution and assembly of Archean gneiss terranes in the Godthåbsfjord region, southern West Greenland: structural, metamorphic and isotopic evidence. Tectonics 8, 573-589.

Pidgeon, R. T. \& Kalsbeek, F. 1978: Dating of igneous and metamorphic events in the Fiskenaesset region of southern West Greenland. Can. J. Earth Sci. 15, 2021-2025.

Pidgeon, R. T., Aftalion, M. \& Kalsbeek, F. 1976: The age of the Ilivertalik granite in the Fiskenæsset area. Rapp. Gronlands geol. Unders. 73, 31-33.

Pillar, J. E. 1985: Geochemistry of high grade gneisses with examples from West Greenland and British Columbia. Unpubl. Ph.D. thesis, University of Leicester, U.K.

Riciputi, L. R., Valley, J. W. \& McGregor, V. R. 1990: Conditions of Archean granulite metamorphism in the GodthabFiskenaesset region, southern West Greenland. J. meta morphic Geol. 8, 171-190.

Robertson, S. 1983: Provisional results of isotopic investigations into quartzo-feldspathic rocks from Kangiussap nunâ, Ivisârtoq sheet, southern West Greenland. Rapp. Grønlands geol. Unders. 115, 56-59.

Robertson, S. 1986: Evolution of the late Archaean lower continental crust in southern West Greenland. In Dawson, J. B., Carswell, D. A., Hall, J. \& Wedepohl, K. H. (eds) The nature of the lower continental crust. Spec. Publ. geol. Soc. Lond. 24, 251-260.

Schiøtte, L., Compston, W. \& Bridgwater, D. 1988: Late Archaean ages for the deposition of clastic sediments belong. ing to Malene supracrustals, southern West Greenland: evidence from an ion probe U-Pb zircon study. Earth planet. Sci. Lett. 87, 45-58.

Schiøtte, L., Compston, W. \& Bridgwater, D. 1989a: U.Pb single-zircon age for the Tinissâq gneiss of southern West Greenland: a controversy resolved. Chem. Geol. 79: 21-30.

Schiøtte, L., Compston, W. \& Bridgwater, D. 1989b: Ion probe U-Th-Pb zircon dating of polymetamorphic orthogneisses from northern Labrador, Canada. Can. J. Earth Sci. 26, 1533-1556.

Secher, K. \& Steenfelt, A. 1981: A preliminary radiometric map of central West Greenland. Unpubl, report, $3 \mathrm{pp}$. Copenhagen: Grønlands Geologiske Undersøgelse.

Taylor, P. N., Moorbath, S., Goodwin, R. \& Petrykowski, A. C. 1980: Crustal contamination as an indicator of the extent of early Archaean continental crust: $\mathrm{Pb}$ isotopic evidence from the late Archaean gneisses of West Greenland. Geochim. Cosmochim. Acta 44, 1437-1453.

Windley, B. F. 1972: Regional geology of early Precambrian high-grade metamorphic rocks in West Greenland Part 1: Kângaitsoq to Ameralik. Rapp. Gronlands geol. Unders. $46,46 \mathrm{pp}$.

Spellings of Greenlandic place names according to the new orthography used in this paper and to the old orthography used on most maps published to date

$\begin{array}{ll}\text { New spelling } & \text { Old spelling } \\ \text { Akulleq } & \text { Akugdleq } \\ \text { Atammik } & \text { Atangmik } \\ \text { Ikkattoq } & \text { Ikátoq } \\ \text { Itilleq } & \text { Itivdleq } \\ \text { Ivinnguit } & \text { Ivínguit } \\ \text { Ivisaartoq } & \text { Ivisârtoq } \\ \text { Kapisillit } & \text { Kapisigdlit } \\ \text { Maniitsoq } & \text { Manîtsoq } \\ \text { Nuuk } & \text { Nûk } \\ \text { Qarliit nunaat } & \text { Qardlît nunât } \\ \text { Qilanngaarsuit } & \text { Qilángârssuit } \\ \text { Qooqqut } & \text { Qôrqut } \\ \text { Qussuk } & \text { Qugssuk } \\ \text { Simiutaa } & \text { Simiutâ } \\ \text { Tasiusarsuaq } & \text { Tasiusarssuaq }\end{array}$

